\title{
Hubungan Kebiasaan Belajar dengan Hasil Belajar IPA Siswa
}

\section{Evi Afriyanti ${ }^{*}$, I Gusti Ngurah Japa ${ }^{2}$, Ndara Tanggu Renda ${ }^{3}$}

1,2 Universitas Pendidikan Ganesha, Singaraja, Indonesia

\section{A R T I CLE I N F O \\ Article history: \\ Received June 08, 2021 \\ Revised June 10, 2021 \\ Accepted July 14, 2021 \\ Available online July 25, 2021 \\ Kata Kunci: \\ Kebiasaan Belajar, Hasil \\ Belajar, IPA \\ Keywords: \\ Learning Habits, Learning \\ Outcomes, Science

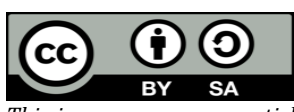 \\ This is an open access article under the CC BY-SA license. \\ Copyright $\left({ }^{\circ} 2021\right.$ by Author. \\ Published by Universitas Pendidikan Ganesha.}

\begin{abstract}
A B S T R A K
Pelaksanaan kegiatan belajar daring, siswa sering menunjukkan adanya kebiasaan belajar yang belum efektif. Penelitian ini bertujuan untuk menganalisis hubungan yang positif dan signifikan antara kebiasaan belajar dengan hasil belajar pada siswa. Penelitian ini merupakan jenis penelitian expost facto tipe korelasional dengan sampel sebanyak 159 orang. Metode pengumpulan data pada penelitian ini menggunakan dua metode yaitu metode kuesioner untuk memperoleh kebiasaan belajar dan metode dokumentasi memperoleh hasil belajar IPA. Metode analisis data yang digunakan dalam penelitian ini adalah metode analisis statistik deskriptif dan analisis statistik inferensial. Analisis deskriptif dilakukan dengan mendeskripsikan frekuensi dari skor angket kebiasaan belajar dan hasi IPA belajar. Sedangkan analisis inferensial digunakan dalam uji asumsi dan uji hipotesis. Untuk menguji hipotesis menggunakan analisis korelasi sederhana yakni membandingkan $r_{\text {hitung }}$ dengan $r_{\text {tabel. }}$ Hasil penelitian adalah terdapat hubungan yang signifikan antara kebiasaan belajar dengan hasil belajar siswa kelas IV yang dibuktikan dengan hasil perhitungan korelasi product moment dengan taraf signifikansi 0.05 ( $\left.r_{\text {hitung }}=0.250>r_{\text {tabel }} 0.159\right)$. Hubungan antara variabel kebiasaan belajar dengan hasil belajar tergolong sedang, dan besarnya hubungan kebiasaan belajar dengan hasil belajar siswa yaitu sebesar 97,5\% dan 2,5\% ditentukan oleh faktor lain di luar penelitian. Jadi kebiasaan belajar siswa akan meberikan pengaruh terhadap hasil belajar siswa.
\end{abstract}

\section{A B S T R A C T}

Every student has different learning habits. In the implementation of online learning activities, students often show ineffective study habits. This study aims to analyze the positive and significant relationship between study habits and student learning outcomes. This research is an ex post facto type of correlational research with a sample of 159 people. Questionnaire as data collection of students' study habits. Data analysis technique with simple correlation is comparing rcount with rtable. The result of the research is that there is a significant relationship between study habits and learning outcomes of fourth grade students as evidenced by the results of the calculation of the product moment correlation $r_{\text {count }}$ $>r_{\text {table }}$ with a significance level of $0.05(0.250>0.159)$, the relationship between the variables of study habits and learning outcomes is classified as moderate, and the magnitude of the relationship study habits with student learning outcomes that is equal to $97.5 \%$ and $2.5 \%$ is determined by other factors outside the research.

\section{PENDAHULUAN}

IPA merupakan salah satu mata pelajaran wajib yang diajarkan di jejang sekolah dasar, materi pembelajaran IPA yakni gejala alam beserta isinya yang dibelajarkan melalui metode ilmiah, sehingga dilakukan melalui proses ilmiah dan menghasilkan produk. Dalam kurikulum 2013, mata pelajaran IPA terintegrasi dengan beberapa mata pelajaran lainnya. Pembelajaran IPA di sekolah dasar memberikan pengetahuan peserta didik mengenai konsep-konsep yang terkandung dalam materi IPA meliputi: makhluk hidup, manusia, tanaman, hewan dan hal-hal yang menyangkut pertumbuhan atau perkembangan pada makhluk hidup serta hal yang berkaitan dengan alam semesta. Selain terdapatnya konsep, hendaknya guru juga dapat menerapkan keterampilan proses sains melalui model-model pembelajaran yang dilakukannya (Awe \& Benge, 2017; Suryani et al., 2019; Widiani et al., 2019). Jadi pembelajaran IPA di sekolah dasar berisi materi yang mengajarkan konsep berupa: makhluk hidup, manusia, tanaman, hewan dan pertumbuhan atau perkembangan pada makhluk hidup serta hal yang berkaitan dengan alam semesta yang diterapkan melalui keterampilan proses. Ketika siswa sekolah dasar mengikuti proses pembelajaran IPA tentunya siswa sekolah dasar memperoleh hasil belajar. Hasil belajar IPA adalah hasil akhir dari proses kegiatan belajar siswa dari seluruh kegiatan siswa dalam mengikuti pembelajaran di kelas dan menerima suatu pelajaran untuk mencapai kompetensi yang berupa aspek kognitif yang diungkapkan dengan menggunakan suatu alat penilaian yaitu tes evaluasi dengan hasil yang dinyatakan dalam bentuk nilai, aspek afektif yang menunjukkan sikap siswa dalam mengikuti pembelajaran, dan aspek psikomotorik yang menunjukkan keterampilan dan kemampuan bertindak siswa 
dalam mengikuti pembelajaran, dimana ketiga aspek tersebut dinyatakan dalam symbol, huruf maupun kalimat. Hasil belajar digunakan oleh guru untuk dijadikan ukuran atau kriteria dalam mencapai suatu tujuan pendidikan(Elisabet et al., 2019; Hamdani, 2020; Naimah, 2021). Jadi dapat disimpulkan, hasil belajar IPA terdiri dari tiga aspek penting yakni kognitif, afektif, dan psikomotor, yang dijadikan acuan oleh guru sebagai kriteria tercapainya tujuan pembelajaran.

Salah satu faktor yang mempengaruhi hasil belajar IPA adalah kebiasaan belajar, Ketidaksamaan tingkat kebiasaan belajar siswa mengakibatkan tingkat pencapaian hasil belajar IPA siswa berbeda. Kebiasaan belajar akan mempengaruhi belajar itu sendiri, yang bertujuan untuk mendapatkan pengetahuan, sikap, kecakapan dan keterampilan, diantaranya, pembuatan jadwal dan pelaksanaannya, membaca dan membuat catatan, mengulangi bahan pelajaran, konsentrasi dan mengerjakan tugas (Annisa \& Fitria, 2021; Sari, 2020). Kebiasaan belajar yang baik akan berimbas pada hasil belajar belajar yang baik juga. Namun, dalam pembelajaran IPA di sekolah dasar pada masa pandemi Covid-19, terdapat beberapa persoalan mengenai kebiasaan belajar siswa. Siswa menghabiskan lebih banyak waktu belajar dalam situasi saat ini jika dibandingkan dengan sebelum pandemi dan dalam pembelajaran yang bersifat praktik atau teknis siswa memperoleh kendala (Bongale et al., 2021; Gunawan et al., 2019). Pembiasaan pembelajaran daring yang tidak memiliki jadwal belajar yang tetap menyebabkan siswa menghabiskan lebih banyak waktu untuk bermain dari pada belajar selama masa pandemi ini sehingga berimbas pada hasil belajar siswa (Agustiningtyas \& Surjanti, 2021). Beberapa persoalan mengenai kebiasaan belajar yang berdampak pada hasil belajar siswa sekolah dasar ditemui di SD N 3 Penarukan saat melaksanakan kegiatan pembelajaran daring pada mata pelajaran IPA, siswa menunjukkan kegiatan pembelajaran yang kurang efektif dengan jarang mengumpulkan tugas tepat waktu, kurang memiliki kesiapan belajar dengan tidak melaksanakan absensi, dan saat kegiatan pembelajaran berlangsung terdapat siswa yang mudah memahami pembelajaran dan ada yang kesulitan memahami materi pembelajaran sehingga hasil belajar IPA kurang optimal.

Adanya kesenjangan antara kebiasaan belajar siswa pada saat pembelajaran daring yang menyebabkan hasil belajar kurang optimal, oleh sebab itu diadakan penelitian yang bertujuan untuk menganalisis hubungan anatara kebiasaan belajar dengan hasil belajar, Hasil penelitan terdahulu menyataka bahwa, setiap siswa memiliki kebiasaan belajar yang berbeda-beda. Pelaksanaan kegiatan belajar siswa seringkali mengungkapkan adanya kebiasaan belajar yang belum efektif (Afriyanti et al., 2021). kebiasaan belajar memberikan kontribusi terhadap hasil belajar IPA $72.25 \%$, dan ada hubungan yang signifikan kebiasaan belajar dengan hasil belajar IPA (Heryanto \& Serimbing, 2020). Hubungan yang begitu signifikan antara kebiasaan belajar yang di lakukan berpengaruh baik dengan hasil belajar siswa dalam pembelajaran (Annisa \& Fitria, 2020). Ada pengaruh yang signifikan antara kebiasaan belajar terhadap hasil belajar siswa kelas V No 135 Pasar Singkut dengan sumbangan 24,11\% dan 75,89\% dipengaruhi variabel lain yang artinya semakin tinggi kebiasaan belajar siswa maka makin tinggi pula hasil belajar yang dicapai siswa (Yantoro \& Universitas, 2016). Perbedaan penelitian terdahulu dan yang sekarang adalah terletak pada situasi penelitian karena penelitian ini dilakukan saat masa pandemi Covid19 dengan situasi pembelajaran dilakukan dirumah atau pembelajaran jarak jauh dengan metode daring dan yang membedakan dengan penelitian terdahulu yaitu penelitian terdahulu bisa melalkukan penelitian dengan secara langsung atau berhadapan langsung dengan siswa akan tetapi pada penelitian ini peneliti hanya bisa melalui perantara guru dan orang tua siswa. Mengingat kebiasaan merupakan faktor dari keberhasilan hasil belajar terutama pada masa pandemi covid-19 yang mana pembelajaran dilaksanakan secara daring dan tanpa kontrol dari seorang guru, sehingga kebiasaanbelajar menjadi faktor yang terpenting. Berdasarkan penjabaran diatas, peneliti akan melakukan penelitian yang bertujuan mengkaji hubungan Antara Kebiasaan Belajar Dengan Hasil Belajar IPA Siswa" yang bertujuan untuk menganalisis antara kebiasaan belajar dengan hasil belajar pada siswa.

\section{METODE}

Penelitian ini adalah terfokus pada ada tidaknya hubungan antar variabel, jenis penelitian ini adalah korelasi. Ada tidaknya keeratan antar variabel dengan menganalisis mengenai pengintegrasian hubungan antar variabel bebas dan terikat, dimana penelitian korelasi adalah penelitian empiris dan sistematis, tidak melakukan pengendalian (kontrol) terhadap variabel bebas secara langsung, karena perwujudan variabel tersebut tidak dapat dimanipulasi (Asri, 2018; Iswandari et al., 2018). Pendekatan yang digunakan dalam penelitian ini yaitu pendekatan kuantitatif karena data yang diperoleh berupa angka-angka dan selanjutnya data tersebut di analisis menggunakan statistik. Menekankan pada analisis pada data numerik (angka) yang kemudian dianalisis dengan metode statistik yang sesuai adalah pendekatan kuantitatif (Hardani et al., 2020; Italiani et al., 2019). Populasi pada penelitian ini adalah seluruh siswa. Populasi adalah keseluruhan gejala/satuan yang diteliti (Priyono, 2016). Jumlah populasi 
keseluruhan adalah 187 siswa. Sedangkan sampel diperoleh melalui proposional random sampling. Dalam penelitian ini sampel sebanyak 159 siswa. Menghemat waktu, tenaga, dan biaya dalam melakukan penelitian adalah tujuan dari penggunaan sampel dalam penelitian ini (Deviana et al., 2017). Memperoleh kebiasaan belajar dan hasil belajar IPA siswa dikumpulkan dengan dua metode. Metode pengumpulan data pada penelitian ini menggunakan dua metode yaitu metode kuesioner untuk memperoleh kebiasaan belajar dan metode dokumentasi memperoleh hasil belajar IPA (Dewi et al., 2020).

Mengenai kuesioner kebiasaan belajar di atas, jenis kuesioner yang dipergunakan bersifat tertutup, dimana pada lembar telah tersedia pilihan jawaban sehingga kuesioner tertutup menggunakan skala likert sebagai acuan untuk menyediakan jawaban (Widiantari \& Suarjana, 2020). Sebelum kuesioner disebarkan kegiatan yang harus dilaksanakan adalah uji judges, setelah uji judges makan instrumen disebarkan dan di uji validitas. Indikator bahwa suatu instrumen telah valid adalah ahli sudah menerima instrumen, baik secara isi maupun formatnya, tanpa ada perbaikan kembali (Yusup, 2018). Sedangkan uji reabilitas. Uji Realiabilitas adalah menguji apakah hasil kuesioner atau angket dapat dipercaya atau tidak (Engkus, 2019). Metode analisis data yang digunakan dalam penelitian ini adalah metode analisis statistik deskriptif dan analisis statistik inferensial. Analisis deskriptif dilakukan dengan mendeskripsikan frekuensi dari skor angket kebiasaan belajar dan hasi IPA belajar. Sedangkan analisis inferensial digunakan dalam uji asumsi dan uji hipotesis (Verawati et al., 2020). Hasil uji statistik inferensial berupa uji normalitas digunakan untuk mengetahui data variabel kebiasaan belajar ( $\mathrm{x}$ ) dan hasil belajar (y) berdistribusi normal atau tidak. Data diuji normalitas menggunakan uji Kolmogorov-Smirnov dengan menggunakan bantuan SPSS 20. Uji linearitas variabel X dan Y, dimana regresi ini berguna untuk mengetahui ukuran derajat keeratan hubungan dan memprediksi besarnya arah hubungan itu, perhitungan uji linieritas menggunakan bantuan SPSS 20. Dalam penelitian ini pengujian hipotesis menggunakan korelasi product moment menggunakan bantuan SPSS 20 dengan hasil besar hubungan antara variabel kebiasaan belajar dengan hasil belajar adalah 0.250 hal ini menunjukkan adanya hubungan yang positif.

\section{HASIL DAN PEMBAHASAN}

Hasil analisis deskriptif diperoleh kecenderungan data distribusi frekuensi skor angket kebiasaan belajar siswa berada pada interval 191-200 sebanyak 35 siswa (22.0\%) dengan arti 22.0\% siswa telah menerapkan kebiasaan belajar yang baik. Selanjutnya data skor angket kebiasaan belajar diinterpretasikan kedalam presentase skor angket kebiasaan belajar dimana terdapat 5 kategori yang mana masing-masing kategori mempunyai kelas interval masing-masing yaitu sangat tinggi, tinggi, sedang, rendah dan sangat rendah. Berdasarkan data tersebut, kecenderungan presentase skor angket kebiasaan belajar pada presentase 76\% - 85\% sebanyak 64 siswa (40.3\%) dengan arti 40.3\% siswa telah menerapkan kebiasaan belajar yang baik dengan kategori tinggi. Hasil belajar siswa diperoleh dari dokumentasi nilai ulangan tengah semester ganjil. Berdasarkan hasil data ulangan semester ganjil, kecenderungan data distribusi frekuensi hasil belajar berada pada interval 80-89 sebanyak 65 siswa (40.9\%) dengan arti 40.9\% siswa telah mencapai hasil belajar yang memuaskan. Kemudian data perolehan nilai hasil belajar siswa dikategorikan kedalam 5 kategori, yang digunakan untuk menginterpretasikan nilai hasil belajar siswa, yaitu baik sekali, baik, cukup, kurang dan gagal, yang mana kelima kriteria tersebut memiliki kelas interval masing-masing. Berdasarkan data, kecenderungan hasil belajar siswa berada pada presentase 77,5 < nilai $\leq 88,5$ sebanyak 65 siswa (40.9\%) dengan arti $40.9 \%$ siswa telah mencapai hasil belajar yang memuaskandengan kategori baik. Setelah uji deskripsi uji dilanjutkan dengan uji prayarat yaitu uji normalitas, hasil uji normalitas diperoleh bahwa data dari kebiasaan belajar dan hasil belajar di atas memiliki nilai signifikan 0,162 dan 0,016 > 0.05 maka dapat dikatakan bahwa data tersebut berdistribusi normal. Sedangkan, uji linearitas variabel X dan Y, dimana regresi ini berguna untuk mengetahui ukuran derajat keeratan hubungan dan memprediksi besarnya arah hubungan itu, perhitungan uji linieritas menggunakan bantuan SPSS 20. Dengan hasil yang didapatkan pada kolom signifikan baris linearity dengan hasil 0.00, berarti dapat disimpulkan bahwa variabel X dan $Y$ memiliki hubungan yang linier. Karena nilai signifikansi $0.00<0.05$. Pengujian hipotesis dalam penelitian ini menggunakan korelasi Pearson Product Momen. Dalam penelitian ini pengujian hipotesis menggunakan korelasi product moment menggunakan bantuan SPSS 20 dengan hasil besar hubungan antara variabel kebiasaan belajar dengan hasil belajar adalah diperoleh Nilai $r_{\text {hitung }}$ yang diperoleh yaitu 0.250 , sedangkan masing $r_{\text {tabel }}$ pada taraf signifikan 5\% adalah 0.159. Dengan demikian dapat dikatakan

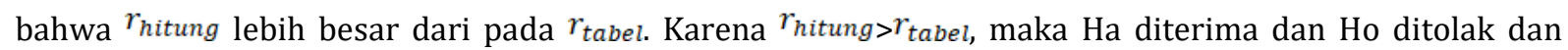
terbukti kebenarannya. Dengan demikian terdapat korelasi antara kebiasaan belajar dengan hasil belajar siswa. Setelah diuji hipotesis, maka untuk mengetahui seberapa besar kontribusi antara variabel X dan Y 
yang dinyatakan dalam bentuk persentase maka harus dihitung dahulu suatu koefisien yang disebut koefisien determinan. Dari hasil perhitungan koefisien determisasi, dinyatakan bahwa nilai koefisien diperoleh sebesar 63\%. Hal ini mengandung pengertian bahwa kebiasaan belajar siswa berkontribusi dan ikut menentukan hasil belajar siswa sebesar 63\%, dan 37\% ditentukan oleh faktor-faktor lainnya seperti pola asuh orang tua, motivasi belajar siswa dan lain sebagainya. Untuk menyatakan besar kecilnya sumbangan variabel X terhadap Y dapat ditentukan dengan koefisien determinasi. Adapun hasil koefisien determinasi menggunakan SPSS 20 adalah dengan hasil output SPSS, diketahui bahwa nilai koefisien determinasi atau R square adalah sebesar 0.975. Nilai R square ini berasal dari pengkuadratan nilai koefisien korelasi atau "R" yaitu $0.988 \times 0.988=0.975$. Besarnya angka koefisien determinasi (R square) adalah 0,975 atau sama dengan 97.5\%. Angka tersebut mengandung makna bahwa variabel Kebiasaan Belajar (X) perpengaruh terhadap variabel Hasil Belajar (Y) sebesar 97.5\%. Sedangkan sisanya (100\% $97.5 \%=2.5 \%$ ) dipengaruhi variabel lain diluar persamaan regresi ini atau variabel yang tidak diteliti.

Berdasarkan hasil analisis deskriptif skor angket kebiasaan belajar siswa dari 159 siswa diketahui bahwa terdapat 52 siswa (32.7\%) mendapatkan kategori sangat tinggi, 64 siswa (40.3\%) mendapatkan kategori tinggi, 28 siswa (17.6\%) mendapatkan kategori sedang, 13 siswa (8.2\%) mendapatkan kategori rendah, dan 2 siswa (1.3\%) mendapatkan kategori sangat rendah.Berdasarkan analisis deskriptif tersebut, kebiasaan belajar siswa dengan tingkat kategori tinggi mempunyai frekuensi yang paling banyak. Hal ini berarti, siswa membentuk kebiasaan belajar mereka dengan cara mengikuti pelajaran dengan baik, belajar secara individu dan berkelompok, belajar menggunakan buku teks, membuat jadwa lpelajaran, membaca dan mencatat, mempelajari bahan pelajaran yang telah dipelajari, siap menghadapi ujian, selalu berkonsentrasi dalam belajar, dan sering mengerjakan tugas. Dengan membiasakan belajar dengan baik maka siswa akan dapat memperoleh berbagai manfaat.

Hasil penelitian bahwa terdapat hubungan antara kebiasaan belajar dengan hasil belajar sejalan dengan pendapat ahli yakni, secara umum, kebiasaan belajar dapat diklasifikasikan menjadi dua kebiasaan belajar yang baik dan kebiasaan belajar yang buruk. kebiasaan belajar yang baik sangat penting untuk keberhasilan pendidikan; karena mereka berkontribusi pada masa depan akademis yang sukses. Perilaku dan kebiasaan belajar yang tekun, rajin, dan daya serta upaya yang dilaksanakan kuat pasti akan menghasilkan hasil yang seimbang dan nilai yang baik,namun apabila perlilaku dan kebiasaan belajar yang kurang baik dikhawatirkan akan menghasilkan hasil yang kurang baik. Kebiasaan belajar mengacu pada dedikasi kebiasaan untuk studi yang ditargetkan. Siswa menentukan bagaimana kegiatan pembelajaran dapat berkembang secara akademis melampaui bidang yang dirasa kekuatan dan bidang yang kurang (Albarado \& Eminita, 2020; Okesina, 2019; Ebele \& Olofu, 2017). Terdapat faktor internal yang mempengaruhi hasil belajar. Salah satu faktor internal tersebut adalah faktor psikologis yang mempengaruhi hasil belajar adalah kebiasaan belajar (Rosyida et al., 2016). Kebiasaan belajar merupakan pengelaman belajar siswa berulang-ulang. Pengalaman belajar yang terus berulang-ulang atau dengan kata lain menjadi sutau kebiasaan belajar akan meningkatkan kompetensi siswa. Kebiasaan belajar yang mempengaruhi belajar antara lain sebagai berikut: membuat dan menata pelaksanaannya seperti, waktu untuk melakukan kegiatan diperhitungkan, membuat catatatan lalu dibaca, materi pembelajaran di ulang, berkonsentrasi, tugas dikerjakan, mempersiapkan diri menghadapi ujian, menghindari terlalu banyak kegiatan yang tidak penting menjelang ujian, setelah memperoleh pelajaran diulang kembali, dan rajin belatih mengerjakan soal. Apabila menerapkan kebiasaan belajar yang baik maka akan mempengaruhi hasil belajar siswa itu sendiri ( Daud \& Lidi, 2020; Wuryani et al., 2019).

Adanya hubungan antara kebiasaan belajar dan hasil belajar IPA siswa sekolah dasar sejalan dengan penelitian terdahulu yakni temuan mengungkapkan hubungan positif antara prestasi akademik dan kebiasaan belajar serta derajat hubungan yang tinggi (Sabbah, 2016). Itu juga ditemukan bahwa kinerja akademik siswa yang memiliki kebiasaan belajar yang baik dan yang buruk berbeda secara dan kebiasaan belajar yang baik menghasilkanprestasi akademik yang tinggi terdapat pengaruh secara signifikan kebiasaan belajar terhadap hasil belajar IPA terpadu siswa besarnya sumbangan relatif kebiasaan belajar terhadap hasil belajar IPA terpadu siswa sebesar 16.2\% (Fitri, 2020) Terdapat hubungan positif pada kategori sedang antara kebiasaan belajar dengan hasil belajar IPA yang diperoleh dari nilai korelasi 0,435 (Setyawan \& Wibowo, 2019). Implikasi dari penelitian korelasional ini adalah dalam pembelajaran dimasa pandemi siswa memperbaiki kebiasaan belajarnya agar dapat meningkatkan hasil belajar IPA dan guru memberikan kegiatan pembelajaran meyenangkan dan fleksibel. Kontribusi dari adanya penelitian korelasional kebiasaan belajar dan hasil belajar adalah menambah wawasan guru, siswa, dan penelitan selanjutnya agar memperhatikan kebiasaan belajar sehingga hasil belajar yang diperoleh optimal. 


\section{SIMPULAN}

Kebiasaan belajar siswa kelas IV sekolah dasar berada pada kategori tinggi artinya siswa telah menerapkan kebiasaan belajar sesuai dengan metode kerja dalam belajar dan kesigapan dalam belajar. Hasil belajar IPA siswa Kelas IV sekolah dasar berada pada kategori baik artinya siswa telah mampu menerapkan kebiasaan belajar dengan baik sehingga berpengaruh pada hasil belajar siswa yang baik yang artinya dapat disimpulkan bahwa ada hubungan yang signifikan antara kebiasaan belajar dengan hasil belajar IPA siswa sekolah dasar. Penelitian selanjutnya disarankan dapat menganalisis hubungan hasil belajar dengan variabel yang berbeda dan pada mata pelajaran lainnya.

\section{DAFTAR PUSTAKA}

Afriyanti, E., Japa, I. G. N., \& Renda, N. T. (2021). Hubungan Kebiasaan Belajar dengan Hasil Belajar IPA Siswa. 04(02). https://doi.org/http://dx.doi.org/10.23887/jp2.v4i2.35188.

Agustiningtyas, P., \& Surjanti, J. (2021). Peranan Teman Sebaya dan Kebiasaan Belajar terhadap Hasil Belajar Melalui Motivasi Belajar di Masa Covid-19. Edukatif: Jurnal Ilmu Pendidikan, 3(3), 794805. https://edukatif.org/index.php/edukatif/article/view/454.

Annisa, D. S., \& Fitria, Y. (2020). Hubungan kebiasaan belajar dengan hasil belajar ipa siswa sekolah dasar. $\begin{array}{lllll}\text { Journal of } & \text { Basic } & \text { Education } & \text { Studies., } & 4(2),\end{array}$ https: //ejurnalunsam.id/index.php/jbes/article/view/3211.

Awe, E. Y., \& Benge, K. (2017). Hubungan Antara Minat Dan Motivasi Belajar Dengan Hasil Belajar Ipa Pada Siswa Sd. Journal of Education Technology, 1(4), 231. https://doi.org/10.23887/jet.v1i4.12859.

Bongale, P., Tandon, C., \& M, A. T. (2021). Effect of the P andemic on Students ' Learning Habits in. Preprints, 1(2), 1-13. https://doi.org/10.20944/preprints202104.0725.v1.

Deviana, N. L. N., Wiarta, I. W., \& Wiyasa, K. N. (2017). Model Pembelajaran Kooperatif Tipe Scramble Berbantuan Bahan Manipulatif Berpengaruh Terhadap Kompetensi Pengetahuan Matematika. Journal of Education Technology, 1(2), 133. https://doi.org/10.23887/jet.v1i2.11775.

Dewi, K. O. R., Murda, I. N., \& Astawan, I. G. (2020). Hubungan Pola Asuh Orang Tua dan Motivasi Belajar Dengan Hasil Belajar PPKN Siswa. Mimbar PGSD Undiksha, 4(1), 53. https://doi.org/http://dx.doi.org/10.23887/jjpgsd.v8i1.24578.

Elisabet, E., Relmasira, S. C., \& Hardini, A. T. A. (2019). Meningkatkan Motivasi dan Hasil Belajar IPA dengan Menggunakan Model Pembelajaran Project Based Learning (PjBL). Journal of Education Action Research, 3(3), 285. https://doi.org/10.23887/jear.v3i3.19451.

Engkus. (2019). Pengaruh Kualitas Pelayanan Terhadap Kepuasan Pasien Di Puskesmas Cibitung Kabupaten Sukabumi. Jurnal Governansi, 5(2), 99-109. https://doi.org/10.30997/jgs.v5i2.1956.

Fitri. (2020). Pengaruh Minat Baca dan Kebiasaan Belajar Terhadap Hasil Belajar IPA Terpadu Siswa $\begin{array}{llll}\text { Kecamatan Sabbangparu. } & \text { UJES, } & \text { 98-103. }\end{array}$ https://doi.org/https://doi.org/10.47323/ujes.v1i3.73.

Gunawan, I. M. ., Murda, I. N., \& Margunayasa, I. G. (2019). Hubungan Kebiasaan Belajar Dan Motivasi Berprestasi Dengan Prestasi Belajar PKn. Media Komunikasi FPIPS, 18(1), 189-200. https: //doi.org/10.23887/mkfis.v18i1.22232.

Hardani, Andriani, H., \& Ustiawaty, J. (2020). Buku Metode Penelitian Kualitatif dan Kuantitatif (Issue March). Pustaka Ilmu.

Heryanto, \& Serimbing, Y. S. B. (2020). Hubungan Kebiasaan Belajar dengan Hasil Belajar IPA. Jurnal Curere, 4(2), 1-10. https://doi.org/http://dx.doi.org/10.36764/jc.v4i2.384.

Iswandari, N., Setiawan, B., Ulya, C., \& Maret, U. S. (2018). Hubungan Anatara Penguasaan Kalimat Efektif dan Kebiasaan Membaca Siswa SMP VIII. Basastra, 6(2), 120-128. https://doi.org/https://doi.org/10.20961/basastra.v6i2.37692.

Okesina, F. A. (2019). Causes of Poor Study Habits of Students as Expressed by Primary School Teachers in Nigeria. Mimbar Sekolah Dasar, 6(1), 1. https://doi.org/10.17509/mimbar-sd.v6i1.16413.

Priyono. (2016). Metode Penelitian Kuantitatif. https://doi.org/10.17509/gea.v14i2.3398.g2390.

Rosyida, F., Utaya, S., \& Budijanto, B. (2016). Pengaruh Kebiasaan Belajar dan Self-Efficacy terhadap Hasil Belajar Geografi Di SMA. Jurnal Pendidikan Geografi, 21(2), 17-28. https: //doi.org/10.17977/um017v21i22016p017.

Sabbah, S. S. (2016). The Effect of Study Habits on English Language Achievement. Arab World English Journal, 7(4), 238-257. https://doi.org/10.24093/awej/vol7no4.16.

Sari, L. (2020). Upaya Menaikkan Kualitas Pendidikan dengan Pemanfaatan Youtube Sebagai Media Ajar Pada Masa Pandemi Covid-19. Jurnal Tawadhu, 4(1), 1074. https://doi.org/123099/index.php/TWD. 
Setyawan, R., \& Wibowo, S. (2019). Hubungan Antara Kebiasaan Belajar Dengan Hasil Belajar Ilmu Pengetahuan Alam (Ipa) Kelas Viii Di Smp Negeri I Kemang Kabupaten Bogor. Jurnal Teknologi Pendidikan, 8(1), 24. https://doi.org/10.32832/tek.pend.v8i1.1730.

Sugiyono. (2009). Motode Penlitian Kuantitatif, Kualitatif, dan R\&D. CV. Alfabeta.

Verawati, R., Tegeh, I. M., \& Antara, P. A. (2020). Hubungan antara Minat Baca dan Motivasi Berprestasi dengan Hasil Belajar Ilmu Pengetahuan Sosial Siswa. Mimbar PGSD Undiksha, 8(3), 351-363. https://doi.org/http://dx.doi.org/10.23887/jjpgsd.v8i3.25518.

Widiantari, N. L., \& Suarjana, I. M. (2020). Hubungan Antara Pola Asuh Orang Tua Dengan Hasil Belajar Siswa Di SMP Swastyastu Tolai. Edukasi: Jurnal Penelitian Dan Artikel Pendidikan, 12(2), 85-94. https://doi.org/10.31603/edukasi.v12i2.4196.

Wuryani, W., Mulyoto, M., \& Sunarto. (2019). Pengaruh Kebiasaan Belajar, Minat Terhadap Hasil Belajar Siswa. Teacher in Educational Research, 1(1), 27-34. https://doi.org/http://dx.doi.org/10.33292/ter.v1i1.7.

Yantoro, D., \& Universitas, F. (2016). Pengaruh Motivasi Dan Kebiasaan Belajar Terhadap Hasil Belajar Matematika Siswa Kelas V Sd No 135 / Vii Pasar Singkut Kecamatan Singkut Kabupaten $\begin{array}{lllll}\text { Sarolangun. } \quad \text { Inovasi Sekolah } & \text { Dasar, }\end{array}$ https://doi.org/https://doi.org/10.36706/jisd.v4i2.8343.

Yusup, F. (2018). Uji Validitas dan Reliabilitas Instrumen Penelitian Kuantitatif. Jurnal Tarbiyah : Jurnal Ilmiah Kependidikan, 7(1), 17-23. https://doi.org/10.18592/tarbiyah.v7i1.2100. 